These considerations illustrate that dynamic analysis may be important in determining optimal reserve policy. Although this is an area of work we intend to pursue, we are confident of the general accuracy and relevance of results from this study.

Secondly, any crop diversions in California will raise the world price for almonds and competing nuts in the years when California diverts supply off the market. A successful reserve program will also increase profitability for foreign producers in the years when supply is diverted. And, because foreign producers will not bear any of the costs associated with crop diversions, they will be effectively "free riders" on any such California strategy.

Any significant increase in foreign production in response to this increased profitability due to the reserve strategy will offset the effect of California's diversions on average returns and will reduce the success of the reserve strategy. A similar response will arise in California: when the policy increases profitability it will encourage greater production, eroding the benefits from the program over time.

\section{Conclusion}

We have analyzed short-term market conditions for U.S. almonds to evaluate alternative market and reserve strategies. Two factors dominated our analysis. The first is the strong signal that there is an unusual abundance of nuts in 1990-91. Along with an exceptionally large carryover from last year, this year's bumper crop in California unfortunately coincides with big crops of both almonds and filberts elsewhere. The second is the high sensitivity of U.S. almond prices to both sales of California almonds and sales of competing product (especially Spanish almonds and Turkish filberts). Demand seems to be significantly inelastic.

Putting these factors together suggests that exceptionally large volumes of California almonds should be taken off the 1990-91 market and either stored for a year or allocated to nonedible uses. We see little evidence to indicate a market failure in the private storage of almonds for edible uses, but results suggest about $8 \%$ of the crop ( 53 million $\mathrm{lb}$ ) could be diverted profitably into an allocated reserve.

J. M. Alston and R.J. Sexton are Associate Professors, Department of Agricultural Economics, UC Davis.

Funding for this study was provided by the Almond Growers Council (AGC). The authors are grateful to the Board of Directors of the $A G C$ for their contributions to this study and to Hoy Carman, Colin Carter and a referee for useful suggestions.

\title{
How disinfectants compare in preventing transmission of fire blight
}

\author{
Beth L. Teviotdale $\square$ Monica F. Wiley $\square$ Dennis H. Harper
}

\section{Clorox, Lysol, and Pine-Sol were superior to rubbing alcohol, Listerine, hydrogen peroxide, Agrimycin 17, or Kocide 101 in pre- venting transmission of fire blight bacteria. Spraying or soaking was more effective than dipping to sur- face-sterilize cutting tools.}

Apple and Asian pear trees are among the many plant species susceptible to fire blight. The disease kills flowers and young shoots, and in very sensitive cultivars, large scaffolds or the entire tree may be destroyed. Cells of the bacterium that causes fire blight, Erwinia amylovora, are deposited onto open flowers by insects or windblown rain. These cells then enter the plant through nectaries at the base of the flower. The pathogen also enters through plant wounds. Fire blight is controlled by frequently applying chemicals during bloom and pruning infected parts as they appear during the season.

While removing infected shoots or branches, pruning shears often become contaminated with E. amylovora. The pathogen, which is present in internal tissues or on the bark surface, infests the shears as the blades pass through the branch or shoot. Even though such cuts are made well below visible symptoms, bacteria may have advanced beyond obviously diseased areas into seemingly healthy tissues. When the next cut is made with contaminated blades, the bacteria may be transmitted and a new infection established.

To protect against such inadvertent inoculations, shears are treated with a disinfectant, usually household bleach, preferably between each cut. Bleach (sodium hypochlorite) is a well-recognized, effective material which, when used correctly, reliably disinfests pruning tools. However, it also is extremely corrosive to metals and may soon render pruning tools worthless. A readily available, effective, inexpensive disinfectant that could be used in the place of bleach would save growers the cost of tool repair and replacement. At the request of several growers, we tested 8 disinfectants, most of which can be purchased over the counter at any drug store, for effectiveness as disinfectants for $E$. amylovora.

\section{Methods}

Our experiments were conducted in two phases: the first tested the effect of disinfectants on survival of E. amylovora in water suspension, and the second examined the ability of the materials to surfacesterilize a cutting tool contaminated with the pathogen. The disinfectants (active ingredients in parentheses) tested were:

- Clorox (sodium hypochlorite 5.25\%),

- Lysol concentrated disinfectant (soap $16.5 \%$, o-phenylphenol $2.8 \%$, o-benzyl-p-chlorophenol $2.7 \%$, ethyl alcohol $1.8 \%$, xylenols $1.5 \%$, isopropyl alcohol $0.9 \%$, tetrasodium ethylenediamine tetraacetate $0.7 \%$ ),

- Pine-Sol (pine oil 19.9\%),

- rubbing alcohol (isopropyl alcohol, 70, 91, and 99\%),

- Listerine (thymol $0.06 \%$, eucalytol $0.09 \%$, methyl salicylate $0.06 \%$, and menthol $0.04 \%$, alcohol $26.9 \%$, benzoic acid, poloxamer 407),

- hydrogen peroxide (hydrogen peroxide USP $3 \%$ ),

- Agrimycin 17 (streptomycin sulfate, $21.2 \%$ ), and

- Kocide 101 (cupric hydroxide, 53\% metallic copper).

Survival in water suspensions. An isolate of E. amylovora was obtained from 'Granny Smith' apple and maintained on Miller-Schroth sorbitol medium (MS). Suspensions of the bacteria were prepared with sterile deionized water and the concentration adjusted to approximately $10^{7}$ cells $/ \mathrm{ml}$ inoculum. One $\mathrm{ml}$ of inoculum was added to $9 \mathrm{ml}$ of each test solution (described below), the inoculated solution shaken briefly ( 3 to 5 seconds), then $0.1 \mathrm{ml}$ spread over each of three MS culture plates. Seeded culture plates were incubated at room temperature for 4 days then the number of colonies present was counted. 


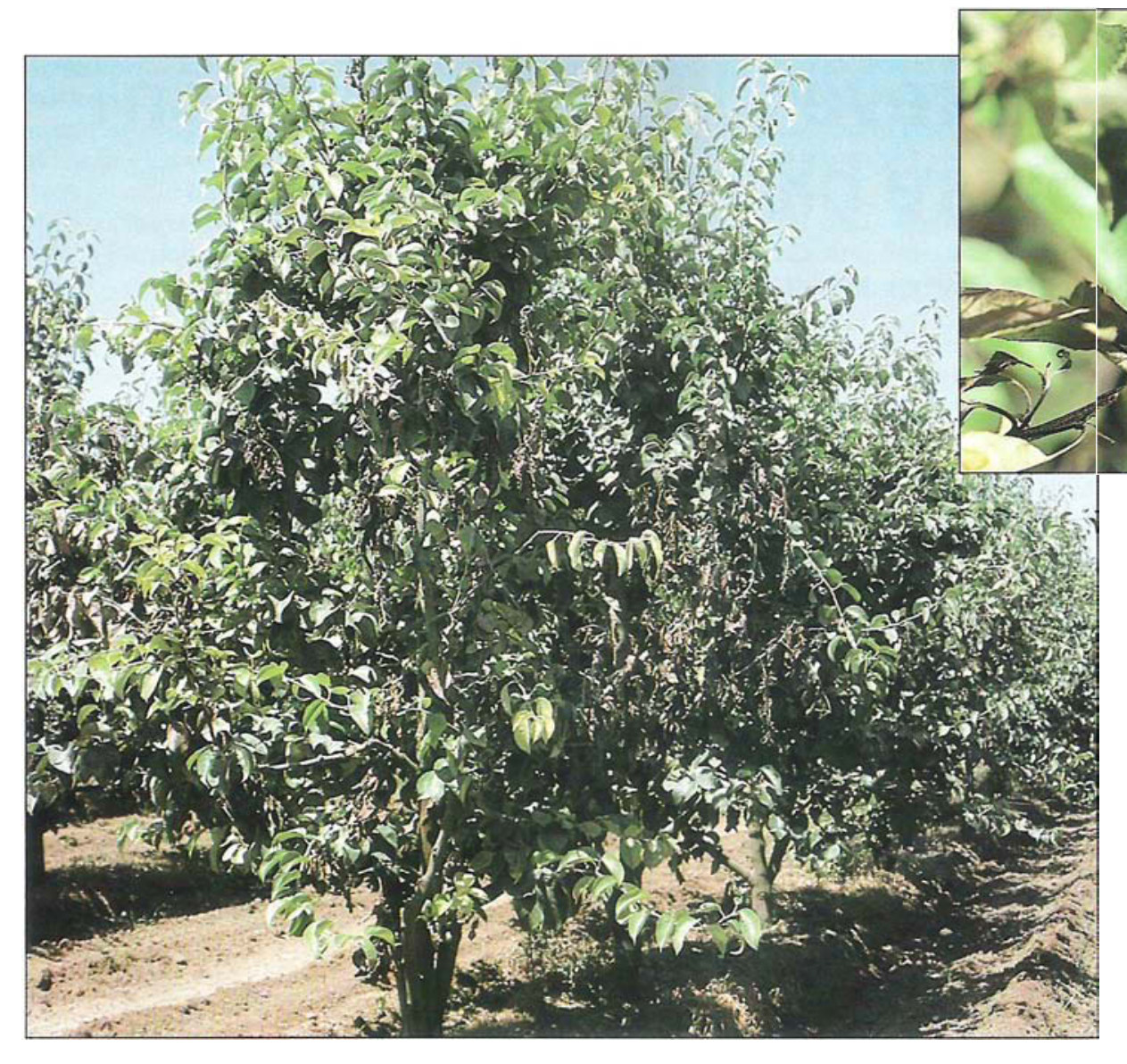

TABLE 1. Effect of eight disinfectants at four concentrations on the survival of Erwinia amylovora

\begin{tabular}{|c|c|c|c|c|}
\hline \multirow[b]{2}{*}{ Disinfectants } & \multicolumn{4}{|c|}{ Number of colonies on three culture plates ${ }^{*}$} \\
\hline & Undiluted & $1: 2$ & $1: 5$ & $1: 10$ \\
\hline Clorox & 0 & 0 & 0 & 0 \\
\hline Lysol & 0 & 0 & 0 & 0 \\
\hline PineSol & 0 & 0 & 0 & 0 \\
\hline Rubbing alcohol, $70 \%$ & 0 & $80_{+}$ & 4 & 260 \\
\hline Rubbing alcohol, $91 \%$ & 0 & $++^{\ddagger}$ & 263 & 310 \\
\hline Rubbing alcohol, $99 \%$ & 0 & + & 320 & 373 \\
\hline Listerine & 0 & 259 & 370 & 488 \\
\hline Hydrogen peroxide, $3 \%$ & 10 & 5 & 6 & 105 \\
\hline Agrimycin $17 \dagger$ & + & + & + & + \\
\hline Kocide $101 \dagger$ & + & + & + & + \\
\hline Water & + & + & + & + \\
\hline
\end{tabular}

Cultured on Miller-Schroth sorbitol medium for 5 days.

Undiluted $=100 \mathrm{ppm}$.

$F_{+}=$Bacterial growth profuse; unable to count individual colonies.

TABLE 2. Comparison of Clorox, Lysol, and Pine-Sol for preventing transmission of fire blight by a scalpel blade contaminated with Erwinia amylovora

\begin{tabular}{|c|c|c|c|c|c|c|c|c|c|c|}
\hline \multirow{3}{*}{$\begin{array}{l}\text { Method } \\
\text { applied }\end{array}$} & \multicolumn{10}{|c|}{ Number of infected fruit ${ }^{*}$} \\
\hline & \multicolumn{3}{|c|}{ Clorox } & \multicolumn{3}{|c|}{ Lysol } & \multicolumn{3}{|c|}{ Pine-Sol } & \multirow{2}{*}{$\begin{array}{l}\text { Wate } \\
\text { contro }\end{array}$} \\
\hline & Undil & $1: 5$ & $1: 10$ & Undil & $1: 5$ & $1: 10$ & Undil & $1: 5$ & $1: 10$ & \\
\hline Dip & 1 & 0 & 1 & 0 & 3 & 2 & 2 & 2 & 2 & 4 \\
\hline Spray & 0 & 0 & 1 & 0 & 0 & 0 & 0 & 1 & 1 & 4 \\
\hline Soak, $1 \mathrm{~min}$ & 0 & 0 & 1 & 0 & 0 & 2 & 0 & 0 & 1 & 4 \\
\hline Soak, $3 \mathrm{~min}$ & 0 & 0 & 0 & 0 & 0 & 1 & 0 & 0 & 1 & 4 \\
\hline Soak, $5 \mathrm{~min}$ & 0 & 0 & 0 & 0 & 0 & 0 & 0 & 0 & 2 & 4 \\
\hline
\end{tabular}

Four detached young Shinseiki Asian pear fruit per treatment. A scalpel blade, contaminated with $E$. amylovora by cutting into an infected Shinseiki Asian pear fruit, was cleansed by each disinfectant before inoculating the four test fruit.

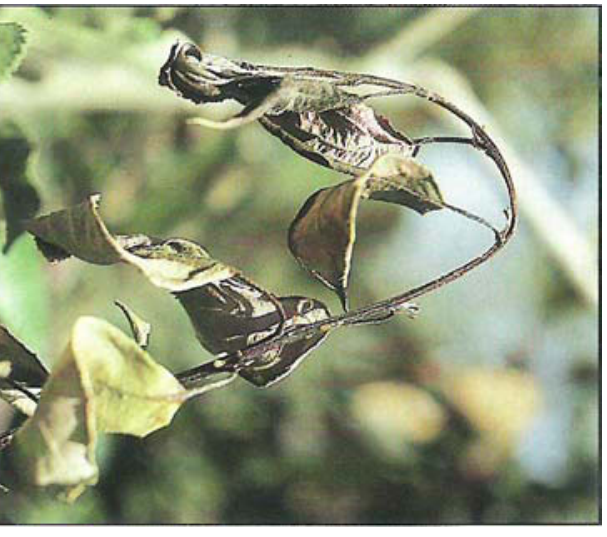

On left, Asian pear trees damaged by fireblight. Above, leaf damage in apple fireblight.

Fresh disinfectants, undiluted and diluted 1:2, 1:5, and 1:10, were tested immediately after opening those that were bottled or after preparing Agrimycin 17 and Kocide 101 suspensions. No growth of E. amylovora on MS medium occurred following exposure to Clorox, Lysol, or PineSol at any concentration (table 1). Bacteria survived after treatment with 1:2,1:5, and 1:10 dilutions of Listerine; after treatment with 70,91 , and $99 \%$ rubbing alcohol, and after tretment with all concentrations of hydrogen peroxide, Agrimycin 17, and Kocide 101. Bacteria were present on control culture plates in this and all other tests.

Deterioration in effectiveness of Clorox, Pine-Sol, and Lysol following exposure to air and light was examined. Open test tubes containing 1:2, 1:5, and 1:10 dilutions of each disinfectant were placed outdoors in direct sunlight or on the laboratory bench under fluorescent light. The laboratory lights were off during the corresponding hours of outdoor darkness. The solutions were inoculated and culture plates seeded at 0-, 2-, 4-, 8-, and 24-hour intervals. Bacteria did not grow after contact with any dilution of these disinfectants whether fresh or exposed to light and air for up to 24 hours.

Three methods that could be used for cleansing pruning tools were compared using 1:10 dilutions of Clorox, Lysol, and Pine-Sol. A bacterial transfer loop was infested by touching a colony of E. amylovora grown on an MS culture plate. The loop was then cleansed with each disinfectant solution by: 1) one dip, 2) one spray on each side of the loop using a hand-held pump sprayer, or 3 ) one 2-minute soak. Immediately after being cleansed, the loop was drawn across the surface of a sterile MS culture plate. All three methods of cleansing with Clorox or Lysol prevented bacterial growth as did the 2-minute soak in Pine-Sol. Culture plates streaked with a 
contaminated loop cleansed by spray or dip with Pine-Sol contained 5 and 11 colonies, respectively.

Sterilization of a cutting tool. For the experiments that follow, inoculum was prepared from an isolate of E. amylovora procured from infected 'Shinseiki' Asian pear. Two types of inoculum were employed: a bacterial suspension, approximately $10^{7}$ cells $/ \mathrm{ml}$, or a detached, artificially infected young Asian pear fruit. Test fruit were healthy, detached young 'Granny Smith' apple and 'Shinseiki' Asian pear fruit. Before use in an experiment, test fruit were surface-sterilized for 5 minutes in a 1:10 dilution of Clorox, rinsed, and allowed to air dry.

When inoculated, two parallel cuts, each cut approximately $1 / 2$-inch long and 1/4-inch deep were made in one side of each fruit. The cutting tool was a scalpel blade which was contaminated with the pathogen either by immersion into the bacterial suspension (immersion) or a cut through an infected fruit (fruit cut).

Immediately after inoculation, the fruit were placed on moist paper towels in plastic crisper boxes and incubated at room temperature for 5 days. Successful inoculation was determined by the presence of bacterial ooze and darkened tissue. Disinfectants were applied to the contaminated scalpel blade by dip, spray (as described above), and 1-, 3-, and 5-minute soaks.

The effectiveness of the dip, spray, and soak cleansing methods were tested in two ways. In one, the scalpel blade was contaminated by immersion, disinfected with 1:10 dilutions of Clorox, Lysol, and Pine-Sol, then used to cut test fruit. Transmission. was completely prevented by spray or soak cleansing with all three disinfectants. When the scalpel blade was cleansed by dipping, one Asian pear and one apple fruit in the Clorox and Lysol treatments, respectively, became infected. In the other test, the scalpel blade was contaminated by fruit cut then cleansed with undiluted, 1:5, and 1:10 dilutions of Clorox, Lysol, and Pine-Sol or with undiluted solutions of Listerine or 70,91, and 99\% rubbing alcohol.

Transmission did not occur when the contaminated scalpel blade was soaked for 1,3 , or 5 minutes in full-strength or $1: 5 \mathrm{di}-$ lutions of Clorox, Lysol, or Pine-Sol. All three disinfectants produced good but not perfect protection when applied as a spray at dilutions of 1:5 or 1:10 (table 2). The dip application method and 1:10 dilution were least effective.

Similar results were obtained in the repeat experiment with the following exceptions: no fruit were infected in the 1:10 dilution treatments of Clorox dip, Pine-Sol spray and 3-minute soak, and one dis- eased fruit was present in the 1:5 and 1:10 Lysol spray treatments. One or more infected fruit were present in all treatments where cuts were made with a scalpel cleansed by Listerine or 70,91 , or $99 \%$ rubbing alcohol. Controls for all experiments in this series included the same procedures just described, however water replaced the disinfectants or the scalpel blade was contaminated and untreated. All water-treated control fruit were healthy and all inoculated control fruit became infected. Four each of apple and Asian pear fruit were treated, and the experiments were conducted twice.

The amount of inoculum present on a contaminated scalpel blade should decrease with each successive cut through healthy fruit tissue. Reduction in transmission following sequential cuts was investigated by infesting the scalpel blade by fruit cut then making two cuts on each of five healthy Asian pear fruit. The fifth fruit received the ninth and tenth cuts after contamination of the blade. Three groups of five fruit were inoculated in this manner. All fruit were diseased and symptoms appeared simultaneously and were uniformly severe.

The effect of inoculum density on transmission of E. amylovora was examined. Scalpel blades were contaminated by a dip into each of seven tenfold serial dilutions of bacterial suspension, ranging from $10^{3}$ through $10^{9}$ cells $/ \mathrm{ml}$. Control inoculations included cuts with: (1) the scalpel blade contaminated by each bacterial concentration then dipped into sterile water, (2) the scalpel blade infested by a fruit cut but untreated, and (3) a sterilized scalpel blade. There were three fruit per treatment.

Two of the three fruit inoculated with inoculum density $10^{3}$ and all three fruit in $10^{4}$ through $10^{9}$ density treatments became infected. Symptoms first appeared on control fruit inoculated by the scalpel contaminated by fruit cut, then on those by inoculum concentrations of $10^{6}$ to $10^{9}$ cells $/ \mathrm{ml}$ and lastly by those of $10^{3}$ to $10^{5}$ cells $/ \mathrm{ml}$. The same pattern was reflected in severity of infection with a decline in tissue discoloration and oozing as inoculum concentration decreased.

We explored the potential for corrosion of metal tools by the disinfectants. Two each surgical carbon steel razor blades were immersed in full strength, 1:5 and 1:10 dilutions of Clorox, Lysol, and PineSol for 2, 4, and 8 hours. When removed, the blades were gently blotted dry and evaluated the next day for corrosion. Discoloration of the blade or the presence of rust was considered evidence of damage to the metal. The experiment was conducted twice. Damage was greatest to razor blades soaked in Clorox and Pine-Sol.
The effect of Clorox and Pine-Sol seemed to be equal in intensity but differed in appearance: Clorox caused a rusted look whereas blades soaked in Pine-Sol were a dark grey with very little rust. Generally, no differences in reaction were distinguished between 4- and 8- hour soak times, the 2-hour soak was slightly less damaging, and damage decreased as dilution increased. Lysol did not affect the blades at any concentration for any period of time soaked.

\section{Conclusions}

The most consistent protection against transmission of E. amylovora was obtained by soaking the contaminated scalpel blade for one or more minutes in either full strength or a 1:5 dilution of Clorox, Lysol, or Pine-Sol. The spray cleansing method, which is favored by many orchardists, was equally effective as the soak method at full strength and nearly as effective at 1:5 dilutions of all materials. Failure to decontaminate the blade occurred most often with the dip cleansing method and the 1:10 dilutions of the disinfectants. Generally, Clorox was most effective in prohibiting transmission, but none of the disinfectants provided $100 \%$ control. This suggests that some transmission may occur under the best of circumstances.

We selected transmission to young fruit as an experimental system because it was not feasible to test disinfectants for ability to protect against transmission by pruning trees. Although our procedure did not ideally imitate pruning branches, it did utilize inoculum from host tissue instead of from culture plates and required that an infection result from the inoculation, not simply growth on a bacterial medium. Tests using water suspensions of the pathogen could have led to erroneous conclusions: materials, dilutions, and cleansing methods shown to be effective against water suspensions of bacteria did not prohibit transmission of fire blight to young fruit when the blade was contaminated by infected fruit.

The economic differences encountered in selecting Clorox, Lysol, or Pine-Sol should be considered. Clorox was the least and Lysol the most expensive material, but Lysol caused the least damage to metal. The value of tools and clothing that may be destroyed by bleach or Pine-Sol must be weighed against the savings in cost of the disinfectant.

B. L. Teviotdale is Extension Plant Pathologist and D. H. Harper is Staff Research Associate, Kearney Agricultural Center; Monica Wiley is undergraduate student, UC Berkeley, and participant in Summer Undergraduate Affirmative Action Research Program (SUAARP), UC Davis. 